\title{
Applying diversity index and dominant species in research and selection of some indigenous plant species to absorb $\mathrm{Pb}, \mathrm{Zn}$
}

\author{
Úng dụng chỉ số đa dạng và ưu thế loài trong nghiên cứu và lựa chọn một số \\ loài thực vật bản địa có khả năng hấp thu $\mathrm{Pb}, \mathrm{Zn}$
}

Research article

Ta Thi Yen*; Pham Thi Mai Thao

Environment Faculty, Ha Noi University of Natural Resources and Environment, 41A Phu Dien Street, Phu Dien Ward, Bac Tu Liem District, Ha Noi City, Vietnam

\begin{abstract}
The study was carried out at Dai Dong and Chi Dao communes, Van Lam District, Hung Yen Province. The biological diversity indexes and dominance index of species were used to identify native plant species which have the ability to absorb $\mathrm{Pb}$ and $\mathrm{Zn}$. The results were verified by applying methods such as plant classification, quadrat cell counting, biological indicators and chemical analysis. Results showed that there are five species of plants with the highest dominant index calculated due to number of individuals in the study area including Bidens pilosa L (33.03\%), Acroceras munroanum (8.14\%), Commelina coelestis (7.83\%), Carex capillacea (5.41\%), Ipomoea aquatic (5.26\%). Verified results showed that Bidens pilosa L, Acroceras munroanum, Commelina coelestis, Ipomoea aquatic can be used to treat $\mathrm{Pb}$ with the absorption concentration of $380 \mathrm{mg} / \mathrm{kg}, 288 \mathrm{mg} / \mathrm{kg}$, $270 \mathrm{mg} / \mathrm{kg}, 223 \mathrm{mg} / \mathrm{kg}$, respectively. Only Commelina coelestis can absorb Zn with the highest concentration of $73 \mathrm{mg} / \mathrm{kg}$. In summary, $\mathrm{Pb}$ absorption of dominant species in the study area is higher than the absorption of $\mathrm{Zn}$.
\end{abstract}

Nghiên cưu được thực hiện tại hai xã Đại Đồng và xã Chỉ Đạo, huyện Văn Lâm, tỉnh Hưng Yên nhằm xác định một số loài thực vật bản địa có khả năng hấp thu Pb, Zn bằng cách sủ dụng chỉ số đa dạng sinh học và chỉ số ưu thế loài. Kết quả được kiểm chứng bằng các phương pháp nhu phân loại thực vạt, đếm ô quadrat, sủ dưng chi số sinh họ và phân tích hóa hoc. Kết quả cho thấy có có năm loài thực vật có chỉ số ư thế cao nhất tính theo số lương cá thể trong khu vực nghiên cứu là: Đơn buốt (33,03\%), Cỏ lá tre (8,14\%), Thài lài (7,83\%), Kiết tóc (5,41\%), Rau muống (5,26\%). Kết quả phân tích kiểm chưng thấy Đơn buốt, Cỏ lá tre, Thài lài, Rau muống có khả năng xủ lý Pb vói giá trị lần luợt là $380 \mathrm{mg} / \mathrm{kg}, 288 \mathrm{mg} / \mathrm{kg}, 270 \mathrm{mg} / \mathrm{kg}, 223 \mathrm{mg} / \mathrm{kg}$. Trong khi đó chí có Thài lài là có khả năng hấp thu Zn với giá trị cao nhất là $73 \mathrm{mg} / \mathrm{kg}$. Nhìn chung khả năng hấp thu Pb của các loài ưu thế tại khu vục nghiên cứu cao hơn so với khả năng hấp thu Zn.

Keywords: heavy metals, spend some diversity, species dominance index

\section{Introduction}

Studies on the heavy metal absorption ability on soil of plant were done by many national and foreign authors and provided meaningful results. Identification of the native plants that have capable to treat heavy metals usually bases on the general principle that is to identify polluted areas. Currently, two approaches used in the selection of plant species are based on the heavy metal content accumulated in plants and tolerance to effects of pollutants. With the first method, the plants will be collected from the contaminated areas. Then the contents of heavy metal in all parts of the plants are analyzed and combined with selection criteria of plant species suitable for initial purpose. To verify the heavy metal treatment ability, we need to optimize growth conditions for plants. This method has high-precision but high cost for chemical analysis. With the second method, contaminated areas, information on the diversity and dominance of the study area must be determined by assessement of changes in diversity and dominance of plants before and after they are affected by the 
wastesource. In the polluted environmental conditions, if any plants are still living, adaptive and are the dominant species, their resistance to contaminants is very high. To verify the heavy metal absorption ability, accumulated levels in the plants will be analyzed. This method is high efficient because it requires low cost by less sample analysis experiments but could select plants with high heavy metal absorption ability.

\section{Materials and methods}

\subsection{Study area}

Dai Dong and Chi Dao communes were chosen for study because both of communes have many households working on metal recycling which discharged $\mathrm{Pb}$ and $\mathrm{Zn}$ for long time. The climatic and soil conditions are represented for Red river delta and suitable for the growth of crops as well as weeds. In this study, we take samples in canals, rice fields and disposal sites receiving waste sources.

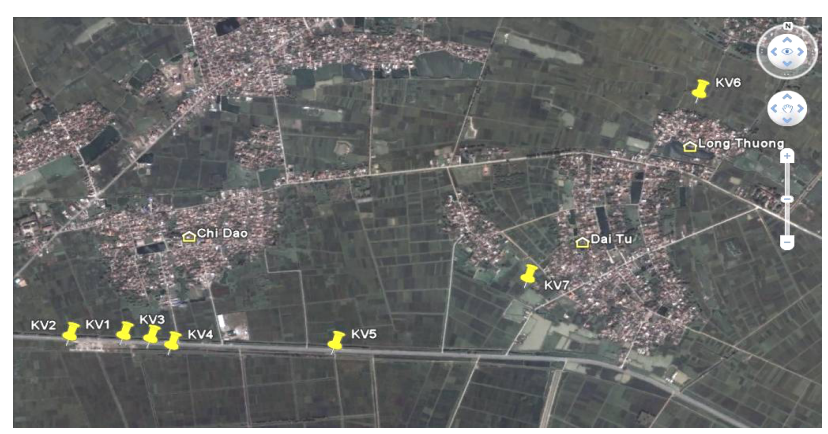

Figure 1: Map of study area (GoogleEarth)

\subsection{Soil and plant sampling method}

Soil samples were taken by specialized tools and same locations with plant samples. Soil samples are taken at the surface $(0-15 \mathrm{~cm})$ at 7 different areas. Two kinds of soil samples include 3 dry samples at the landfill (KV1, KV6, KV7) and 4 semi-submerged samples collected at rice fields and canals (KV2, KV3, KV4, KV5). While, the vegetable cells were taken from the east - west - south north - center. In the wetland areas (canals), the plants were taken at every 2 meters in the distance from upstream to downstream. Based on current conditions and the sampling location, we selected 38 plant samples at the study areas. The detail of sampling locations is shown in the Table 1.

\subsection{Biodiversity survey method}

* Botanical classification method

Collected plants at study sites were identified through the references combined with expert advice.

* Vegetation survey method

Vegetation survey was conducted based on standard cell counting methods (O quadrat) with dimensions of $120 \times 80$ $\mathrm{cm}$ of each cell.

* Biostatistics method

In this method, the biological indicators applied include:

Shannon \& Weiner index:

$$
\mathrm{H}^{\prime}=-\sum_{1=1}^{s} p i \ln p i
$$

Simpson index:

$$
\mathrm{Cd}=\sum_{i=1}^{S}\left(\frac{n i}{N}\right)^{2}
$$

Where pi: Percentage of individuals in the $i^{\text {th }}$ species

$$
\begin{aligned}
& \mathrm{pi}=\mathrm{ni} / \mathrm{N} \\
& \mathrm{ni}: \text { Total individual of } \mathrm{i} \text { species } \\
& \mathrm{N} \text { : Total individual of all species }
\end{aligned}
$$

\subsection{Analysis method}

* Soil samples: organic carbon was analyzed by Walkley Black, $\mathrm{pH}$ by $\mathrm{pH}$ meter, total $\mathrm{Pb}$ and $\mathrm{Zn}$ by Asano - Kato method, 1997.

* Plant samples: heavy metal concentrations were analyzed by Asano Kato method.

\section{Results and discussion}

\subsection{Diversity and dominance of plant}

\begin{tabular}{|c|c|c|}
\hline Location symbol & Soil sample & Sampling location \\
\hline KV1 & Đ1 & Landfill - Chi Dao commune \\
\hline KV2 & Đ2 & Rice filed and Landfill - Chi Dao commune \\
\hline KV3 & Đ3, B3 & Canals - Chi Dao commune \\
\hline KV4 & Đ4 & Rice field - Chi Dao commune \\
\hline KV5 & Đ5, B5 & Canals - Chi Dao commune \\
\hline KV6 & Đ6, B6 & Ma Chuc, Long Thuong, Dai Dong \\
\hline KV7 & Đ7 & Dai Tu, Dai Dong \\
\hline
\end{tabular}

\subsubsection{The list of plants appearing on the study area}

The study results showed that 37 plant species belonging to 17 families appeared in the study area (Table 2).

Table 1. Soil and plant sampling location

Note: KV-Location; $Đ-$ Soil 
Table 2. The list of plants appearing on the study area

\begin{tabular}{|c|c|c|c|}
\hline No & Family & Latin name & Vietnamese name \\
\hline 1 & Asteraceae & Bidens pilosa $L$ & Don buot \\
\hline 2 & & Artemisia vulgaris L.. & Ngai cuu \\
\hline 3 & & $S p 1$ & Cai dong \\
\hline 4 & & Eclipta prostrata (L.) & Nho noi \\
\hline 5 & & Torenia asiatica L. & Ngo dai \\
\hline 6 & & Grangea maderaspanata (L.) & Cai dong \\
\hline 7 & & Gynura divaricata $L$ & Bầu đất \\
\hline 8 & Poaceae & Acroceras munroanum & Co la tre \\
\hline 9 & & Eleusine indica (L.) & Co man trau \\
\hline 10 & & Cynodon dactylon & Co ga \\
\hline 11 & & Panicum paludosum & Ke nuoc \\
\hline 12 & & Echinochloa crus - galli (L.) & Co long vuc nuoc \\
\hline 13 & & $S p 1$ & $\mathrm{Co}$ \\
\hline 14 & & $S p 2$ & Co \\
\hline 15 & & $S p 3$ & $\mathrm{Co}$ \\
\hline 16 & Commelinaceae & Commelina coelestis & Thai lai \\
\hline 17 & Cyperaceae & Carex capillacea & Kiet toc \\
\hline 18 & & Cyperus serotinus Rottb & Co ba canh \\
\hline 19 & & Cyperus rotundus L.. & Co gau \\
\hline 20 & Convolvulaceae & Ipomoea aquatic & Rau muong \\
\hline 21 & Urticaceae & Parietaria debilis & Tuong anh \\
\hline 22 & Solanaceae & Physalis angulala & Tam bop \\
\hline 23 & & Solanum americanum & Lulu duc \\
\hline 24 & Onagraceae & Ludwidgia adscendens (L.) & Dua nuoc \\
\hline 25 & & Ludwidgia octovalvis & Rau muong \\
\hline 26 & Amaranthceae & Alternanthera sessilis & Rau deu \\
\hline 27 & Marsileaceae & Marsilea quadrifolia $L$. & Co bo \\
\hline 28 & Polygonaceae & Polygonum hydropiper L.. & Nghe nuoc \\
\hline 29 & & Polygonum hydropiper L. & Nghe ram \\
\hline 30 & & Rumex chinensis Campd & Chut chit \\
\hline 31 & Verbenaceae & Lantana camara L. & Ngu sac \\
\hline 32 & Araceae & Coloscasia esculenta $L$. & Khoai nuoc than trang \\
\hline 33 & & Coloscasia Black & Khoai nuoc than tim \\
\hline 34 & Pontederiaceae & Eichhornia crassipes & Beo tay \\
\hline 35 & Mackinlayoideae & Centello asiatica & Rau ma \\
\hline 36 & Gleicheniaceae & Dicranopteris dichotoma & Guot \\
\hline 37 & Pteridaceae & Pteris vittata $L$ & Duong xi \\
\hline
\end{tabular}

\subsubsection{Diversity and dominance of plants}

Table 3 and 4 showed that in 7 study areas, KV1 had the lowest diversity but dominant value was the highest, while KV3 was opposite.

Diversity and dominance of plant species were homologous at all study areas based on the number of individual, fresh and dry weight. If diversity value was calculated only based on the number of individuals at the dry land areas (KV1, KV6, KV7), KV6 had the highest diversity with the presence of 15 species. This is the agricultural area so that many species appear there than in other locations. At the low field locations, KV4 was more diverse than KV2 with three analysis methods, while semisubmerged area, the diversity at the KV3 was higher than KV5. If calculated on the entire 7 reaserch areas, KV3 had the highest diversity beacause there are many canals at this location.

If the diversity was calculated due to the fresh weight, the results were $3.03 ; 2.93 ; 3.54$ at dry land KV6, low field KV4, canals KV3, respectively. These locations had the highest diversity value. The dry weight based diversity values were also same with the above results.

Dominant values calculated according to individual were $0.84 ; 0.18 ; 0.16$ at dry land KV1, low field KV4, canals $\mathrm{KV} 5$, respectively. If due to the fresh weight, the dominant values at the dry land KV7, low field KV2, canals KV5 were, respectively, $0.45 ; 0.21 ; 0.18$. These areas also had the greatest values. It was the same value in the case of the fresh weight. 
Table 3. Diversity value of the research areas

\begin{tabular}{llcccc}
\multirow{2}{*}{ Kind of land } & Location & Total of species & \multicolumn{3}{c}{ Diversity (H) } \\
\cline { 4 - 6 } Dry land & KV1 & 6 & Individual & Fresh weight & Dry weight \\
\cline { 3 - 6 } & KV6 & 15 & 0.38 & 1.73 & 1.83 \\
\multirow{2}{*}{ Low field } & KV7 & 7 & 2.13 & 3.03 & 2.98 \\
& KV2 & 8 & 1.31 & 1.53 & 1.49 \\
Canal & KV4 & 14 & 1.91 & 2.41 & 2.33 \\
& KV3 & 21 & 1.99 & 2.93 & 2.74 \\
& KV5 & 14 & 2.42 & 3.54 & 2.57 \\
\end{tabular}

Table 4. Dominant values of the research areas

\begin{tabular}{llcccc}
\multirow{2}{*}{ Kind of land } & Location & Total of species & \multicolumn{3}{c}{ Dominance (Cd) } \\
\cline { 4 - 6 } Dry land & & 6 & Individual & Fresh weight & Dry weight \\
& KV1 & 15 & 0.84 & 0.36 & 0.33 \\
\multirow{2}{*}{ Low field } & KV6 & 7 & 0.16 & 0.17 & 0.17 \\
& KV2 & 8 & 0.34 & 0.45 & 0.46 \\
Canal & KV4 & 14 & 0.16 & 0.21 & 0.24 \\
& KV3 & 21 & 0.18 & 0.15 & 0.19 \\
& KV5 & 14 & 0.10 & 0.10 & 0.10 \\
\end{tabular}

\subsection{The relationship between $\mathrm{Pb}$ and $\mathrm{Zn}$ con- centrations in soil with diversity and dominance of plant at the study area}

Analytical results showed that all soil at the study areas were polluted by $\mathrm{Pb}$ and $\mathrm{Zn}$ except KV5 and KV6 that had Zn concentration lower than QCVN 03: 2015/BTNMT. At dry land locations (KV1, KV7, KV6), Pb and Zn concentrations in soil were higher than in other locations. In particular, at $\mathrm{KV} 1$ the values of $\mathrm{Pb}$ and $\mathrm{Zn}$ in soil were highest that reached to $23426 \mathrm{mg} / \mathrm{kg}$ and $237 \mathrm{mg} / \mathrm{kg}$, respectively. This may because there were many $\mathrm{Pb}$ recycling households operating in this area for a long time. At semi-submerged lands including low field (KV2, KV4) and canals (KV3, KV5), $\mathrm{Pb}$ and $\mathrm{Zn}$ concentrations in soil were high because of receiving polluted wastewater from landfills at the high terrain. In these locations, the KV2 and KV3 had high $\mathrm{Pb}$ and $\mathrm{Zn}$ concentrations in soil $\mathrm{The} \mathrm{Pb}$ content was $131,778 \mathrm{mg} / \mathrm{kg}$ and $\mathrm{Zn}$ was $1559 \mathrm{mg} / \mathrm{kg}$ at $\mathrm{KV} 2$, while $\mathrm{Pb}$ was $102,762 \mathrm{mg} / \mathrm{kg}$ and $\mathrm{Zn}$ was $366 \mathrm{mg} / \mathrm{kg}$ at KV3 (Table $5)$.

Table 5. $\mathrm{Pb}$ and $\mathrm{Zn}$ concentrations in soil and the diversity and dominance values

\begin{tabular}{|c|c|c|c|c|c|}
\hline Kind of land & Location & Pb (mg/kg) & Zn (mg/kg) & Diversity (H) & Dominance (Cd) \\
\hline & KV1 & 23426 & 237 & 0.38 & 0.84 \\
\hline \multirow[t]{3}{*}{ Dry land } & KV7 & 134 & 213 & 1.31 & 0.34 \\
\hline & KV6 & 164 & 117 & 2.13 & 0.16 \\
\hline & KV2 & 131778 & 1559 & 1.91 & 0.16 \\
\hline \multirow[t]{3}{*}{ Low field } & KV4 & 1822 & 260 & 1.99 & 0.18 \\
\hline & KV3 & 102762 & 366 & 2.42 & 0.1 \\
\hline & KV5 & 7321 & 142 & 2.05 & 0.16 \\
\hline \multicolumn{2}{|c|}{ QCVN 03:2015/BTNMT } & 70 & 200 & & \\
\hline
\end{tabular}

3.2.1 The relationship between the $\mathrm{Pb}$ and $\mathrm{Zn}$ concentrations in soil and the diversity

Each plant species has the resistance differently with different heavy metal contents in soil. Figure 2 and 3 shows that the trend of the diversity fluctuations at dry land, low field and cannels is different. At the dry land (KV1, KV7, KV6), when the Pb and $\mathrm{Zn}$ concentrations in soil increase from KV6 (164 mg/kg Pb; $117 \mathrm{mg} / \mathrm{kg} \mathrm{Zn}$ ) to KV1 (23,436 mg/kg Pb; $237 \mathrm{mg} / \mathrm{kg} \mathrm{Zn})$, the diversity decreases from KV6 (2.13) to KV1 (0.38). This pointed out that the $\mathrm{Pb}, \mathrm{Zn}$ affected on the flora in these areas. The similar results were found at the low field areas. Concentrations of $\mathrm{Pb}$ and $\mathrm{Zn}$ in soil at $\mathrm{KV} 4$ were $1,822 \mathrm{mg} / \mathrm{kg}$ and $260 \mathrm{mg} / \mathrm{kg} \mathrm{Zn}$, repestively and increased to KV2 (131,778 $\mathrm{mg} / \mathrm{kg} \mathrm{Pb} ; 1,559 \mathrm{mg} / \mathrm{kg} \mathrm{Zn}$ ), the diversity decreased from KV4 (1.99) to KV2 (1.91). At the canals, the trend was reverse when
$\mathrm{Pb}$ concentration increased, the diversity also increased, KV5 (7,321 mg/kg Pb; $142 \mathrm{mg} / \mathrm{kg} \mathrm{Zn)} \mathrm{increased} \mathrm{to} \mathrm{KV3} \mathrm{(102} 762$ $\mathrm{mg} / \mathrm{kg} \mathrm{Pb} ; 366 \mathrm{mg} / \mathrm{kg} \mathrm{Zn}$ ), the diversity increased from KV5 (2.05) to KV3 (2.42). Both areas (KV3, KV5) were high plant diversity values, it showed that these plant species in these locations had good resistance with heavy metal infected conditions.

3.2.2. The relationship between the $\mathrm{Pb}$ and $\mathrm{Zn}$ concentration in soil and the dominance

Figure 4 and 5 show the relationship between the concentrations of $\mathrm{Pb}$ and $\mathrm{Zn}$ in soil in all study locations and the dominance at the study areas. 
At the dry land areas (KV1, KV7, KV6), when the Pb, Zn concentrations in soil increased from KV6 (164 mg/kg Pb; $117 \mathrm{mg} / \mathrm{kg} \mathrm{Zn})$ to $\mathrm{KV} 1$ (23,426 mg/kg Pb; $237 \mathrm{mg} / \mathrm{kg} \mathrm{Zn})$, the dominant values increased from KV6 $(0.16)$ to KV1 (0.84). It means that the potential appearance of the dominant species was highest at KV1 because of the high levels of heavy metal contamination in soil, only some species can withstand and then become the dominant species.

In the wetland areas (low fields and canals), the trend was opposite with the dry areas. At the low field location, when the $\mathrm{Pb}, \mathrm{Zn}$ concentration in soil increased from KV4 (1822 $\mathrm{mg} / \mathrm{kg} \mathrm{Pb} ; 260 \mathrm{mg} / \mathrm{kg} \mathrm{Zn})$ to $\mathrm{KV} 2(131,778 \mathrm{mg} / \mathrm{kg} \mathrm{Pb}$; $1,559 \mathrm{mg} / \mathrm{kg} \mathrm{Zn})$, the dominant values decreased from KV4 (0.18) to KV2 (0.16), and similar to the canal area. This may be that the flora at the submerged areas had high uniformity.

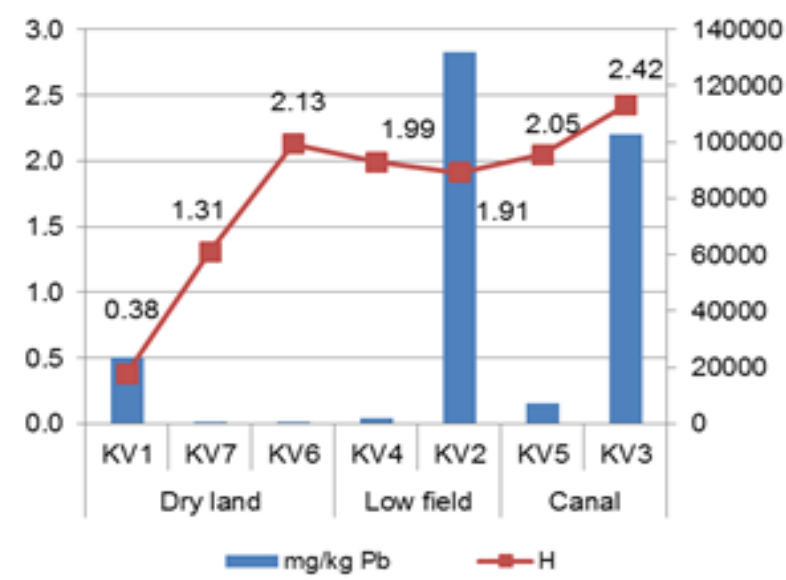

Figure 2. The relationship between the $\mathbf{P b}$ concentration in soil and the diversity

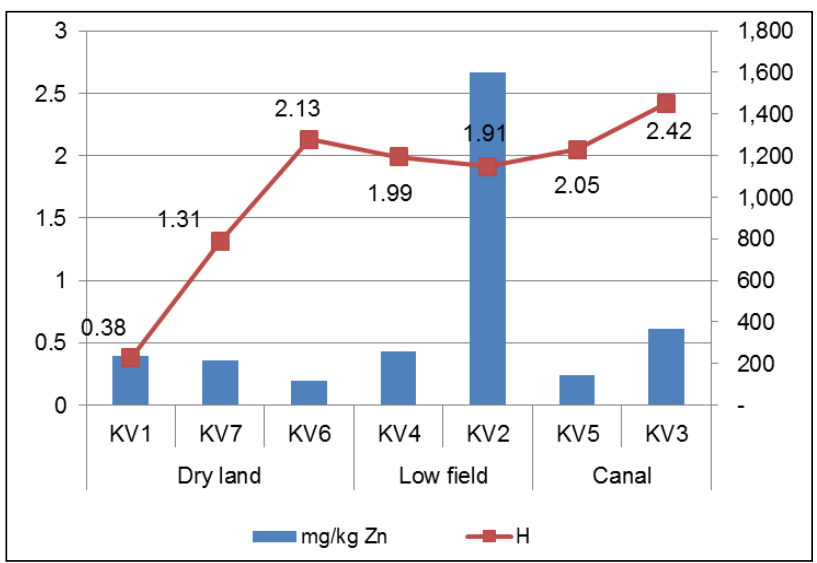

Figure 3. The relationship between the $\mathrm{Zn}$ concentration in soil and the diversity

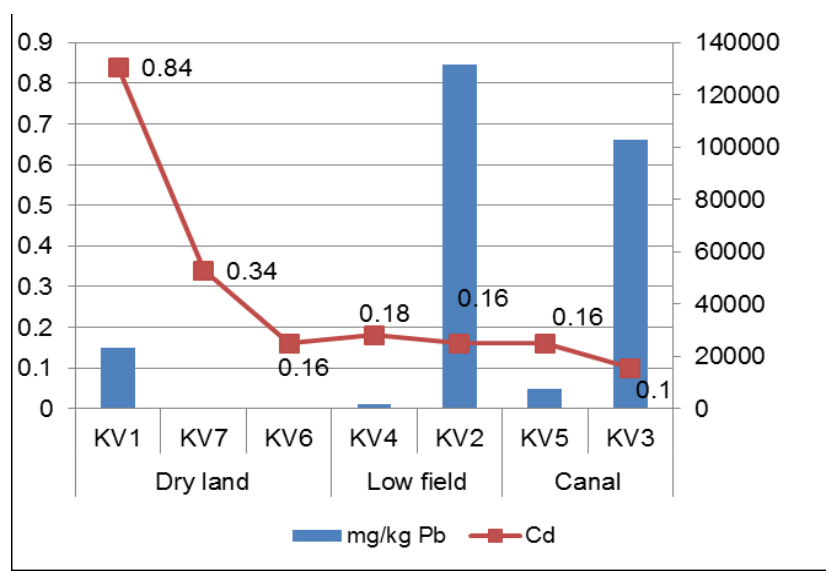

Figure 4. The relationship between the $\mathrm{Pb}$ concentration in soil and the dominance

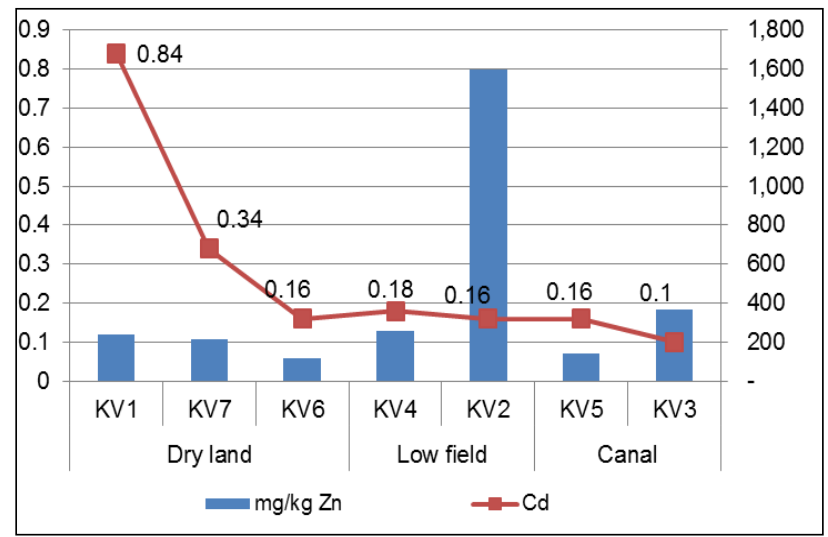

Figure 5. The relationship between the $\mathrm{Zn}$ concentration in soil and the dominance

\subsection{Determination of the dominant species in the study area}

Figure 5 and Table 6 showed that if the dominant values calculated by individual species, there were five dominant species including Bidens pilosa L (33.03\%), Acroceras munroanum $8.14 \%$ ), Commelina coelestis (7.83\%), Carex capillacea (5.41\%), Ipomoea aquatic (5.26\%) (Table 6).

If taking into account of the fresh weight, the dominant species are Don buot (20,86\%), Tam bop (10,30\%), Thai lai $(9,94 \%)$, Rau muong $(7,61 \%)$, Co la tre $(7,75 \%)$. In which, Tam bop had the most dominant and followed by Don buot, these species had high biomass values and only appeared at the disposal areas (KV1). If based on the dry weight, there were five dominant species including Bidens pilosa L. (19.94\%), Physanlis angulala (9.81 \%), Acroceras munroanum (7. $55 \%)$, Commelina coelestis (7.41 $\%)$, Carex capillacea (7.23\%) (Figure 6).

Table 6. The number and fresh, dry weight of plant species appearing in the study area

\begin{tabular}{lllll} 
Vietnamese name & Latin name & Individual, \% & Fresh weight, \% & Dry weight, \% \\
\hline Don buot & Bidens pilosa L. & $\mathbf{3 3 . 0 3}$ & $\mathbf{2 3 . 8 6}$ & $\mathbf{1 9 . 9 4}$ \\
Co la tre & Acroceras munroanum & $\mathbf{1 0 . 2 6}$ & $\mathbf{7 . 7 5}$ & $\mathbf{7 . 5 5}$ \\
Thai lai & Commelina coelestis & $\mathbf{7 . 4 1}$ & $\mathbf{9 . 9 4}$ & $\mathbf{7 . 4 1}$ \\
Kiet toc & Carex capillacea & $\mathbf{5 . 1 2}$ & 4.24 & $\mathbf{7 . 2 3}$ \\
Rau muong & Ipomoea aquatic & $\mathbf{5 . 1 6}$ & $\mathbf{7 . 6 1}$ & 6.37 \\
Co long vuc nuoc & Echinochloa crus - galli (L.) & 4.91 & 1.18 & 2.58
\end{tabular}




\begin{tabular}{|c|c|c|c|c|}
\hline Vietnamese name & Latin name & Individual, \% & Fresh weight, \% & Dry weight, \% \\
\hline Ngai cuu & Artemisia vulgaris L.. & 4.29 & 0.74 & 0.83 \\
\hline Co man trau & Eleusine indica (L.) & 3.43 & 1.18 & 1.18 \\
\hline Co ba canh & Cyperus serotinus Rottb & 2.65 & 2.29 & 3.36 \\
\hline Tuong anh & Parietaria debilis & 2.39 & 1.10 & 0.96 \\
\hline Cải & Spl & 2.13 & 0.01 & 2.25 \\
\hline Tam bop & Physanlis angulala & 2.04 & 10.30 & 9.81 \\
\hline Co & Sp3 & 1.97 & 1.61 & 2.06 \\
\hline Dua nuoc & Ludwidgia adscendens (L.) & 1.91 & 2.76 & 2.66 \\
\hline Rau deu & Alternanthera sessilis & 1.90 & 1.78 & 2.24 \\
\hline Co bo & Marsilea quadrifolia L. & 1.60 & 0.29 & 0.33 \\
\hline Nghe nuoc & Polygonum hydropiper L.. & 1.06 & 4.42 & 6.49 \\
\hline Ngu sac & Lantana camara $L$ & 1.03 & 0.23 & 0.32 \\
\hline $\mathrm{Co}$ & $S p 2$ & 0.91 & 1.01 & 1.32 \\
\hline khoai nuoc & Coloscasia esculenta L. & 0.94 & 2.25 & 0.99 \\
\hline Nho noi & Eclipta prostrata (L.) & 0.80 & 0.31 & 0.23 \\
\hline Beo tay & Eichhornia crassipes & 0.70 & 2.50 & 1.77 \\
\hline Nghe ram & Polygonum hydropiper L. & 0.61 & 0.23 & 0.21 \\
\hline Ngo dai & Torenia asiatica $L$. & 0.52 & 1.10 & 0.95 \\
\hline Rau muong & Ludwidgia octovalvis & 0.44 & 0.06 & 0.06 \\
\hline Lulu duc & Solanum americanum & 0.37 & 3.12 & 3.39 \\
\hline Co & $S P 1$ & 0.65 & 0.19 & 0.11 \\
\hline Co ga & Cynodon dactylon & 0.84 & 0.54 & 1.43 \\
\hline Co gau & Cyperus rotundus L.. & 0.28 & 0.03 & 0.03 \\
\hline Rau ma & Centello asiatica & 0.22 & 0.04 & 0.03 \\
\hline Guot & Dicranopteris dichotoma & 0.17 & 2.85 & 4.87 \\
\hline Duong xi & Pteris vittata $L$. & 0.10 & 0.21 & 0.35 \\
\hline Khoai nuoc than tim & Colocasia Black & 0.06 & 0.50 & 0.26 \\
\hline Ke nuoc & Panicum paludosum & 0.04 & 0.54 & 0.36 \\
\hline Cai dong & Grangea maderaspanata $L$. & 0.03 & 0.01 & 0.03 \\
\hline Chut chit & Rumex chinensis Campd.. & 0.03 & 0.04 & 0.03 \\
\hline Bau dat & Gynura divaricata L. & 0.01 & 0.04 & 0.02 \\
\hline
\end{tabular}

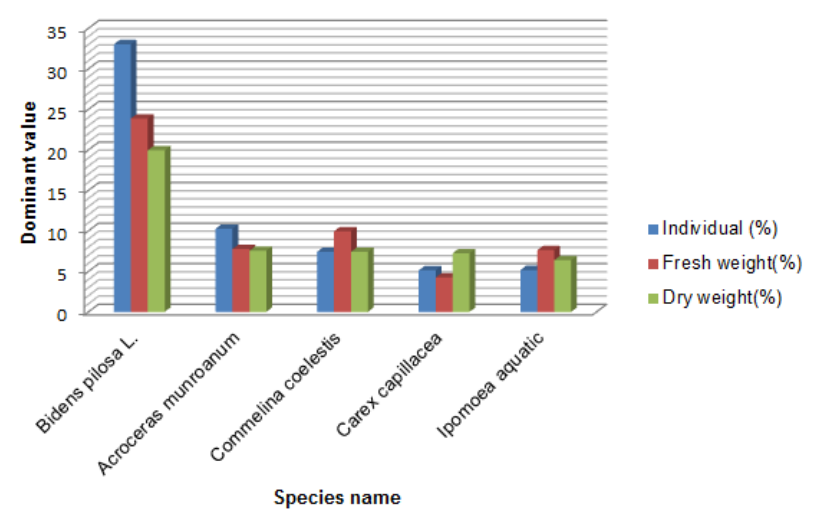

\subsection{Verification of $\mathrm{Pb}$ and $\mathrm{Zn}$ absorption ability of the selected plant species}

Table 7 showed that Bidens pilosa L and Acroceras munroanum had ability to absorb $\mathrm{Pb}$ respectively $380 \mathrm{mg} / \mathrm{kg}$ and $288 \mathrm{mg} / \mathrm{kg}$ at the dry area, higher than other species within the same area. For $\mathrm{Zn}$, Acroceras munroanum can absorb $69 \mathrm{mg} / \mathrm{kg} \mathrm{Zn}$ and higher than the remaining Bidens pilosa $L$ and Physalis angulala. At the wetland areas, Commelina coelestis and Ipomoea aquatic can absorb $\mathrm{Pb}$ at $270 \mathrm{mg} / \mathrm{kg}$ and $223 \mathrm{mg} / \mathrm{kg}$, respectively. Ipomoea aquatic can absorb $\mathrm{Zn}$ at $59 \mathrm{mg} / \mathrm{kg}$ and better than Cyperus serotinus Rottb and Carex capilacea.

Figure 6: The dominant values of five plant species

Table 7. Pb and $\mathrm{Zn}$ absorption of the selected plants

\begin{tabular}{|c|c|c|c|c|c|c|}
\hline $\begin{array}{c}\text { Vietnamese } \\
\text { name }\end{array}$ & Latin name & Location & $\begin{array}{c}\mathrm{Pb}(\mathrm{mg} / \mathrm{kg}) \\
\text { in soil }\end{array}$ & $\begin{array}{c}\mathrm{Zn}(\mathrm{mg} / \mathbf{k g}) \\
\text { in soil }\end{array}$ & $\begin{array}{c}\mathrm{Pb}(\mathrm{mg} / \mathrm{kg}) \text { in } \\
\text { plant }\end{array}$ & $\underset{\substack{\text { plant } \\
\text { Zn }(\mathrm{mg} / \mathrm{kg})}}{\text { in }}$ \\
\hline Don buot & Bidens pilosa $L$ & & & & 380 & 58 \\
\hline Tam bop & Physalis angulala & KV1 & 23426 & 237 & 71 & 33 \\
\hline Co la tre & Acroceras munroanum & & & & 288 & 69 \\
\hline Thai lai & Commelina coelestis & KV3 & $\begin{array}{l}102762 \\
245\end{array}$ & 366 & 270 & 73 \\
\hline
\end{tabular}




\begin{tabular}{|c|c|c|c|c|c|c|}
\hline $\begin{array}{c}\text { Vietnamese } \\
\text { name }\end{array}$ & Latin name & Location & $\begin{array}{l}\mathrm{Pb}(\mathrm{mg} / \mathrm{kg}) \\
\text { in soil }\end{array}$ & $\begin{array}{l}\mathrm{Zn}(\mathrm{mg} / \mathrm{kg}) \\
\text { in soil }\end{array}$ & $\begin{array}{c}\mathrm{Pb}(\mathrm{mg} / \mathrm{kg}) \text { in } \\
\text { plant }\end{array}$ & $\underset{\text { plant }}{\mathrm{Zn}(\mathrm{mg} / \mathrm{kg})}$ in \\
\hline Rau muong & Ipomoea aquatic & & & & 223 & 59 \\
\hline Co ba canh & Cyperus serotinus Rottb & \multirow{2}{*}{$\mathrm{KV} 2$} & \multirow{2}{*}{131778} & \multirow{2}{*}{1559} & 42 & 46 \\
\hline Kiet toc & Carex capillacea & & & & 37 & 54 \\
\hline
\end{tabular}

\section{Conclusions}

The results showed that the study area was contaminated lightly by $\mathrm{Zn}$ and seriously by $\mathrm{Pb}$, especially at the KV1, $\mathrm{KV} 2, \mathrm{KV} 3$ with the corresponding concentrations of 23 $426 \mathrm{mg} / \mathrm{kg} ; 131,778 \mathrm{mg} / \mathrm{kg} ; 102,762 \mathrm{mg} / \mathrm{kg}$ of $\mathrm{Pb}$. There were 37 species belonging to 17 families identified. In which, there were 5 dominant species accounted due to individual number as Bidens pilosa L. (33,03\%), Acroceras munroanum $(8,14 \%)$, Commelina coelestis $(7,83 \%)$, Carex capillacea (5,41 \%), Ipomoea aquatic $(5,26 \%)$

At the dry land locations (KV1, KV7, KV6), when Pb and $\mathrm{Zn}$ concentrations in soil increased, diversity decreased. $\mathrm{Pb}$ and $\mathrm{Zn}$ concentrations in soil of KV6 were $164 \mathrm{mg} / \mathrm{kg}$; $117 \mathrm{mg} / \mathrm{kg}$ and were 23,426 mg/kg; $237 \mathrm{mg} / \mathrm{kg}$ at KV1 respectively, the diversity decreased from KV6 (2.13) to KV1 (0.38). The same trend was found at the dry area. At the canal areas, the concentrations of $\mathrm{Pb}$ and $\mathrm{Zn}$ in soil were $7,321 \mathrm{mg} / \mathrm{kg} ;, 142 \mathrm{mg} / \mathrm{kg}$ respectively at $\mathrm{KV} 5$ and increased at KV3 $(102,762 \mathrm{mg} / \mathrm{kg} \mathrm{Pb}, 366 \mathrm{mg} / \mathrm{kg} \mathrm{Zn})$, the diversity also increased from 2.05 to 2.42 . In contrast to the diversity, the dominant value changes in the same direction with the increase of the heavy metal concentrations. In seven researched plant species, Bidens pilosa L., Acroceras munroanum, Commelina coelestis and Ipomoea aquatic had the highest $\mathrm{Pb}$ absorption ability. While $\mathrm{Zn}$ is absorbed the highest by Commelina coelestis. Commelina coelestis and Bidens pilosa $L$. can be used to treat both $\mathrm{Pb}$ and $\mathrm{Zn}$ in polluted soil.

\section{References}

[1] Sekara, A., Poniedzialek, M., Ciura, J., Jedrszczyk, E. 2005. Zinc and Copper Accumulation and Distribution in the Tissues of Nine Crops: Implications for Phytoremediation. Polish Journal of Environmental Studies, 14(6), 829-835

[2] Piechalak, A., Tomaszewska, B., Baralkiewicz, D., Malecka, A. 2002. Accumulation and detoxification of lead ions in legumes. Phytochemistry, 60(2), 153162

[3] Piechalak, A., Malecka, A., Barałkiewicz, D., Tomaszewska, B. 2008. Lead uptake, toxicity and accumulation in Phaseolus vulgaris plant. Biologia Plantarum, 52(3), 565-568.

[4] Hinman, C. 2005. Low impact development, Technical guidance manual for Puget Sound. Appendix 6:
Sampling of plant species studied for phytoremediation. Publication No. PSAT 05-03, Washington State University, Pierce County Extension, Tacoma, WA

[5] Boonyapookana, B., Parkpian, P., Techapinyawat, S., DeLaune, R.D., Jugsujinda, A. 2005. Phytoaccumulation of lead by sunflower (Helianthus annuus), tobacco (Nicotiana tabacum), and vetiver (Vetiveria zizanioides). J Environ Sci Health A Tox Hazard Subst Environ Eng., 40(1), 117-137

[6] Chaney, R.L., Malik, M., Li, Y.M., Brown, S.L., Brewer, E.P., Angle, J.S., Baker, AJM. 1997. Phytoremediation of soil metals. Current Opinion in Biotechnology, 8(3), 279-284

[7] Green, C., Hoffnagle, A. 2004. Phytoremediation field studies database for chlorinated solvents, pesticides, explosives and metals. US EPA, Washington, DC.

[8] Deng, D.M., Shu, W.S., Zhang, J., Zou, H.L., Lin, Z., Ye, Z.H., Wong, M.H. 2006. Zinc and cadmium accumulation and tolerance in populations of Sedum alfredii. Environ. Pollut., 147(2), 381-386

[9] EPA. 2000. Introduction to phytoremediation. EPA /600/ R - 99/ 107. www.epa.gov/swertio 1/download/ remed/introphyto.pdf

[10] Porebska, G., Ostrowska, A. 1999. Heavy Metal Accumulation in Wild Plants: Implications for Phytoremediation. Pol. J. Environ. Stud., 8(6), 433-442

[11] Salt, D.E., Blaylock, M., Kumar, N.P., Dushenkov, V., Ensley, B.D., Chet, I., Raskin, I. 1995. Phytoremediation: A Novel Strategy for the Removal of Toxic Metals from the Environment Using Plants. Biotechnology (NY), 13(5), 468-474.

[12] ITRC, 1999. Phytoremediation Decision Tree. The Interstate Technology and Regulatory Cooperation Work Group. https://clu-in.org/download/partner/phytotree.pdf

[13] Hernández-Allica, J., Becerril, J.M., Garbisu, C. 2007. Assessment of the phytoextraction potential of high biomass crop plants. Environ Pollut., 152(1), 3240 .

[14] Myung Chae Jung, Iain Thornton. 1996. Heavy metal contamination of soils and plants in the vicinity of a lead-zinc mine, Korea. Applied Geochemistry, 11(12), 53-59.

[15] Kara, Y. 2005. Bioaccumulation of $\mathrm{Cu}, \mathrm{Zn}$ and $\mathrm{Ni}$ from the wastewater by treated Nasturtium officinale. Int. J. Environ. Sci. Technol., 2(1), 63-67. 